\title{
MENINGKATKAN KREATIVITAS TEMATIK SISWA DENGAN PENJUMLAHAN PENGURANGAN MENGGUNAKAN PENDEKATAN MASTERY LEARNING KELAS II SD NEGERI 065853 MEDAN DENAI
}

\author{
Megawati ${ }^{1}$ \\ Surel:megawati@gmail.com
}

\begin{abstract}
This type of research is classroom action research that aims to improve students' mathematics learning activities in the subject matter of addition and subtraction using the Mastery Learning approach in Class II of SD Negeri 065853 Medan Denai. The subjects in this study were Class II students of SD Negeri 065853 Medan Denai with the number of students 32 people in the academic year 2017/2018. Data analysis techniques used by using percentage data analysis.
\end{abstract}

\section{Keywords: Mastery Learning, Creativity}

\begin{abstract}
ABSTRAK
Jenis penelitian ini adalah penelitian tindakan kelas yang bertujuan untuk meningkatkan aktivitas belajar matematika siswa pada materi pokok penjumlahan dan pengurangan dengan menggunakan pendekatan Mastery Learning di Kelas II SD Negeri 065853 Medan Denai. Subjek dalam penelitian ini adalah siswa Kelas II SD Negeri 065853 Medan Denai dengan jumlah siswa 32 orang tahun ajaran 2017/2018. Teknik analisis data yang digunakan dengan memakai analisis data persentase.
\end{abstract}

Kata Kunci : Mastery Learning, Kreativitas

\section{PENDAHULUAN}

Matematika

merupakan

bidang studi yang dipelajari oleh semua siswa dari SD, SMP, SMA, hingga perguruan tinggi. Banyak orang yang memandang matematika sebagai bidang studi yang paling sulit, ini dikarenakan guru dalam menerangkan kurang jelas dan kurang menarik perhatian, serta pada umumnya guru terlalu cepat dalam menerangkan materi pelajaran, disamping itu penggunaan metode yang digunakan kurang tepat.
Sehingga siswa dalam memahami dan menguasai materi masih kurang akibatnya nilai yang diperoleh siswa rendah. Ini merupakan masalah utama yang dihadapi oleh para guru matematika. Meskipun demikian, semua orang harus mempelajarinya karena merupakan sarana untuk memecahkan masalah kehidupan sehari-hari. Sama seperti halnya bahasa, membaca, dan menulis, kesulitan belajar matematika harus diatasi sedini mungkin, kalau tidak siswa akan menghadapi banyak 
masalah karena hampir semua bidang studi memerlukan matematika yang sesuai.

\begin{tabular}{lrr}
\multicolumn{1}{c}{ Guru diharapkan } & mampu \\
meningkatkan aktivitas & siswa \\
sehingga siswa & dapa \\
mengembangkan bakat & dan \\
potensinya. Disini anaklah yang
\end{tabular}
beraktivitas, berbuat dan harus aktif sendiri. Dalam belajar sangat diperlukan adanya aktivitas, tanpa aktivitas proses belajar mengajar tidak mungkin berlangsung dengan baik. Dengan adanya aktivitas, proses belajar mengajar terutama pelajaran matematika jika dilakukan dengan baik akan banyak mendapatkan keuntungan dan kemudahan bagi siswa dan juga bisa diharapkan tingkat kegagalan dapat diperkecil sedangkan keberhasilan dapat diperbesar.

Berdasarkan dari beberapa faktor yang dapat mempengaruhi proses belajar mengajar siswa tersebut, faktor pendekatan yang akan penulis coba yaitu pembelajaran dengan menggunakan pendekatan belajar tuntas (mastery learning) yang memiliki pengaruh lebih baik, karena pendekatan belajar tuntas mempersyaratkan peserta didik menguasai secara tuntas seluruh standar kompetensi maupun METODE PENELITIAN

Penelitian ini adalah Penelitian Tindakan Kelas (PTK). Penelitian ini dilaksanakan selama dua bulan mulai bulan Maret sampai Mei 2018.

Subjek dalam penelitian ini adalah siswa Kelas II SD Negeri 065853 Medan Denai yang terdiri kompetensi dasar mata pelajaran tertentu. Di dalam pendekatan ini, setiap peserta didik diberikan waktu sesuai dengan yang diperlukan untuk mencapai suatu tingkat penguasaan, dan jika dia menghabiskan waktu yang diperlukan, maka besar kemungkinan peserta didik akan mencapai tingkat penguasaan kompetensi (berhasil). Tetapi jika peserta didik tidak dapat menggunakan waktu yang diperlukan secara penuh, maka tingkat penguasaan kompetensi peserta didik tersebut belum optimal. Dengan menggunakan pendekatan tersebut, guru dapat membentuk siswa menjadi beberapa kelompok, bagi siswa yang telah berhasil mencapai tujuan pembelajaran dapat menjadi tutor dalam kelompok dengan bimbingan guru. Maka terciptalah anak didik yang dapat menguasai tujuan pembelajaran, sehingga di dalam kelas tidak terjadi anak cerdas akan mencapai semua tujuan pembelajaran sedangkan anak didik yang kurang cerdas mencapai sebagian tujuan pembelajaran atau tidak mencapai sama sekali tujuan pembelajaran.

dari satu kelas berjumlah sebanyak 40 siswa.

Objek dalam penelitian ini adalah tindakan sebagai meningkatkan aktivitas belajar siswa dalam mata pelajaran matematika dengan model pendekatan Mastery 
learning di Kelas II SD Negeri $065853 \mathrm{Kec}$ Medan Denai Tahun Ajaran 2017/2018.

\section{HASIL DAN PEMBAHASAN}

Tindakan yang dilakukan oleh guru diberikan khusus pada materi pokok Penjumlahan dan pengurangan pecahan. Peneliti berusaha terlibat dalam upaya kerjasama dengan guru mata pelajaran matematika Kelas IV dengan tujuan untuk mendapatkan pemahaman yang lebih efektif terhadap perubahan yang dihasilkan untuk penggunaan pendekatan mastery learning yang diajarkan kepada siswa Kelas II SD Negeri No. $065853 \mathrm{kec}$ Medan Denai tahun ajaran 2017/2018.

\section{Pengamatan}

Pelaksanaan tindakan pada pertemuan I dihadiri oleh 40 siswa. Dari 40 siswa dalam kelas terdapat 7 siswa yang melakukan aktivitas mendengarkan, 7 siswa tersebut mendengarkan penjelasan guru dengan baik, siswa ini juga mendengarkan hasil diskusi kelompok orang lain, 7 siswa mendengarkan dengan baik pendapat teman satu kelompok dan dari hasil observasi terlihat 7 siswa mendengarkan hasil diskusi atau berdiskusi yang persentasenya 17,5\%. Sementara 33 siswa lainnya terlihat kurang aktif karena dari aktivitas mendengarkan yang dilakukan hanya tampak dua bahkan
Pada tahap ini observer dan guru melakukan pengamatan selama kegiatan pembelajaran berlangsung. Mencatat semua hal yang diperlukan dan yang terjadi selama pelaksanaan tindakan berlangsung dengan menggunakan daftar cheklist pada lembar observasi untuk mengukur aktivitas belajar siswa dan lembar observasi mengukur kemampuan guru.

\section{Hasil observasi siswa pada pertemuan I}

Berdasarkan lembar observasi yang diamati dan diisi oleh observer, terdiri dari 8 indikator dan 32 deskriptor. Hasil observasi aktivitas belajar siswa pada siklus I pertemuan 1 untuk frekuensi siswa yang aktif.

masih banyak yang satu deskriptor saja.

Dari 40 siswa yang menaruh minat terdapat 3 siswa yang bersemangat dalam belajar, 3 siswa yang serius untuk belajar, 3 siswa tidak terlambat datang kesekolah dan 3 siswa tidak ingin absen ke sekolah karena sayang untuk melewati pelajaran matematika yang persentasenya $7,5 \%$. Sementara 37 siswa lainnya terlihat kurang aktif karena dari aktivitas menaruh minat yang dilakukan hanya tampak dua bahkan satu deskriptor saja.

Dari hasil rata-rata kelas dan persentase jumlah siswa yang aktif pada setiap indikator menunjukkan bahwa aktivitas belajar siswa dalam 
Penjumlahan dan pengurangan pecahan sangat rendah. Oleh sebab itu, peneliti melaksanakan perbaikan pengajaran yaitu dengan melakukan pertemuan 2 pada siklus I.

\section{Hasil observasi guru siklus I pertemuan I}

Pada pertemuan pertama siklus I, guru dalam penguasaan terhadap materi pelajaran yaitu penguasaan bahan materi dengan baik mendapat 3 point, kemudian guru dalam materi pelajaran sesuai dengan standar kompetensi (SK) dan tujuan pembelajaran mendapat 2 point, kemudian guru dalam menyajian materi jelas mendapat 2 point, dan kemudian guru dalam penyajian materi secara sistematis mendapat 2 point.

Dalam kegiatan evaluasi penilaian, guru membuat tes-tes formatif, baik secara terbimbing maupun mandiri mendapat 3 point, guru melihat siswa mendapatkan nilai yang objektif, baik individu maupun kelompok mendapat 2 point, siswa cepat dalam menyelesaikan tugas-tugas mendapat 2 point, guru bisa membuat siswa serius dalam mengerjakan tugas-tugas mendapat 1 point.

Dalam kegiatan pemberian instruksi, guru menyimpulkan materi pelajaran dengan baik mendapat 3 point, dalam memberi pengayaan mendapat 2 point, dan dalam memberi tugas guru mendapat 3 point, dan guru dalam menginformasikan materi selanjutnya mendapat 2 point. Dari hasil observasi guru dengan menggunakan pendekatan mastery learning pada siklus I pertemuan I diperoleh nilai 58,75.

Pelaksanaan tindakan pada pertemuan kedua ini dihadiri 40 siswa. Disini guru menjelaskan materi kemudian membagi siswa menjadi 6 kelompok secara merata dengan setiap kelompok menggunakan tutor untuk mempermudah siswa dalam memahami materi pelajaran. Dari 40 siswa dalam kelas terdapat 12 siswa yang melakukan aktivitas mendengarkan, 12 siswa tersebut mendengarkan penjelasan guru dengan baik, siswa ini juga mendengarkan hasil diskusi kelompok orang lain, 12 siswa mendengarkan dengan baik pendapat teman satu kelompok dan dari hasil observasi terlihat 12 siswa mendengarkan hasil diskusi atau berdiskusi yang persentasenya $30 \%$. Sementara 28 siswa lainnya terlihat kurang aktif karena dari aktivitas mendengarkan yang dilakukan hanya tampak dua bahkan masih banyak yang satu deskriptor saja.

Dari keterangan di atas siklus I pada pertemuan 1 dan 2 , peneliti dalam kegiatan observasi dilakukan untuk melihat aktivitas belajar siswa dalam melakukan kegiatan belajar dengan menggunakan pendekatan mastery learning sesuai dengan prosedur, pada beberapa aktivitas seperti mendengarkan, menjawab pertanyaan, mengemukakan pendapat, menulis/mencatat, membaca, diskusi, mengerjakan tugas-tugas, dan menaruh minat 
seperti yang tertera pada lembar observasi aktivitas belajar siswa dan terdapat juga lembar observasi guru dalam menggunakan pendekatan mastery learning Berdasarkan kumpulan data yang diperoleh kolaborasi antara guru dan teman sejawat yang membantu peneliti, ternyata sebagian besar aktivitas belajar siswa masih rendah, baik secara individu maupun klasikal.

\section{Hasil observasi guru siklus I pertemuan II}

Pada pertemuan kedua siklus I, guru dalam penguasaan terhadap materi pelajaran yaitu penguasaan bahan materi dengan baik mendapat 3 point, kemudian guru dalam materi pelajaran sesuai dengan standar kompetensi (SK) dan tujuan pembelajaran mendapat 2 point, kemudian guru dalam menyajian materi jelas mendapat 3 point, dan kemudian guru dalam penyajian materi secara sistematis mendapat 2 point.

Dalam kegiatan pemberian instruksi, guru menyimpulkan materi pelajaran dengan baik mendapat 3 point, dalam memberi pengayaan mendapat 2 point, dan dalam memberi tugas guru mendapat 3 point, dan guru dalam menginformasikan materi selanjutnya mendapat 3 point. Deskripsi hasil observasi guru pada pertemuan II dapat dilihat pada tabel lampiran 9. Dari hasil observasi guru dengan menggunakan pendekatan mastery learning pada siklus I pertemuan II diperoleh nilai 70 .

\section{Refleksi I}

Dari hasil penelitian siklus I, pertemuan 1 dan 2 dapat ditarik kesimpulan bahwa aktivitas belajar siswa dari lembar observasi, sebagian besar aktivitas siswa tergolong rendah dan pembelajaran yang dilakukan belum mencapai target walaupun aktivitas siswa terjadi perubahan menuju kearah yang lebih baik. Karena peneliti melihat siswa masih kurang dalam memanfaatkan waktu yang diberikan. Agar siswa dapat menyelesaikan soal Penjumlahan dan pengurangan pecahan, dan siswa masih sulit dalam memahami Penjumlahan dan pengurangan pecahan terlebih lagi pada pecahan berpenyebut berbeda. Hal ini dikarenakan para siswa kurang aktif dalam proses pembelajaran berlangsung, banyak siswa yang ribut, siswa takut disuruh kedepan untuk mengerjakan soal, dan kurang memperhatikan peneliti saat menjelaskan materi penjumlahan dan pengurangan pecahan berpenyebut sama dan berpenyebut tidak sama serta tidak berani mengemukakan pendapat dan sulit untuk diajak komunikasi di kelas. Hal tersebut disebabkan oleh siswa belum terlalu mengenal peneliti, sehingga peserta didik masih takut dan malu. Siswa juga belum terbiasa dengan pendekatan mastery learning. Oleh karena itu peneliti harus melanjutkan penelitiannya ke siklus II. Peneliti berharap pada siklus II aktivitas belajar siswa meningkat.

\section{Tahap Perencanaan Tindakan II}

Sebelum melaksanakan tindakan penelitian pada siklus II, 
peneliti dan guru mempersiapkan segala sesuatu yang menunjang untuk pelaksanaan tindakan penelitian. Dalam kegiatan ini mempersiapkan materi pokok, serta pendekatan pembelajaran yang dapat digunakan dalam mempelajari Penjumlahan dan pengurangan pecahan.

\section{Tahap Pelaksanaan II}

Pada pertemuan pertama siklus II, siswa diberikan pengertian tentang materi pelajaran Penjumlahan dan pengurangan pecahan dengan menggunakan pendekatan mastery learning. Kegiatan belajar pada pertemuan I adalah dengan kembali memberi motivasi dan aktivitas siswa untuk bisa belajar lebih aktif.

Pada pertemuan kedua siklus II, siswa diberikan pengertian kembali kepada peneliti tentang materi pecahan campuran mengenai Penjumlahan dan pengurangan pecahan dan melanjutkan pembahasan yang belum selesai pada pertemuan I siklus II. kegiatan yang dilakukan guru pada pertemuan II ini membagi siswa menjadi beberapa kelompok, setiap kelompok mengerjakan tugas yang diberikan peneliti dan menjelaskan langkahlangkah serta apa-apa saja yang harus dilakukan siswa dalam mengerjakan tugas dengan adanya bimbingan peneliti dan waktu yang telah ditentukan dengan pendekatan mastery learning. Setelah selesai mengerjakan tugas kelompok dengan waktu yang telah ditentukan peneliti meminta masing-masing perwakilan kelompok kedepan mengerjakan soal tersebut dipapan tulis dan siswa lainnya memeriksa soal yang dikerjakannya, gambar 4.13 proses belajar dan mengerjakan tugas pada siklus II pertemuan II.

Agar siswa merasa senang dan lebih termotivasi dan terus aktif dalam belajar, maka peneliti memberikan tepuk tangan yang meriah sebagai penghargaan baik pada tiap-tiap kelompok maupun individu supaya siswa tersebut semakin rajin dalam mengerjakan tugas dan tidak bosan dalam belajar matematika. Sementara itu guru Kelas IV dan observer mengamati proses belajar mengajar dan aktivitas yang dilakukan siswa dan peneliti dari awal hingga akhir pelajaran, gambar 4.14 proses belajar mengajar siklus II pertemuan II.

\section{Pengamatan}

Pada tahap ini observer dan guru melakukan pengamatan selama kegiatan pembelajaran berlangsung dari awal hingga akhir. Hal ini bertujuan untuk mengetahui sejauh mana pemahaman siswa terhadap materi pembelajaran, serta melihat partisipasi siswa dalam pembelajaran dengan menggunakan pendekatan mastery learning sehingga terjadi peningkatan aktivitas belajar. Mencatat semua hal yang diperlukan dan yang terjadi selama pelaksanaan tindakan berlangsung dengan acuan lembar observasi untuk mengukur aktivitas belajar siswa pada mata pelajaran matematika dalam pendekatan mastery learning dan 
lembar observasi untuk mengukur kemampuan guru.

\section{Hasil Observasi Aktivitas Siswa} Siklus II Pertemuan I

Dari hasil rata-rata kelas dan persentase jumlah siswa yang aktif pada setiap indikator menunjukkan bahwa aktivitas belajar siswa pada pertemuan ini dalam kategori sedang. Oleh karena itu, peneliti melaksanakan perbaikan pengajaran yaitu dengan melakukan pertemuan 2 pada siklus II. Dalam hal ini peneliti sudah lebih menguasai metode pembelajaran dengan menggunakan pendekatan mastery learning dengan memperhatikan semua siswa dalam melaksanakan kegiatan pembelajaran baik secara individu maupun kelompok.

Berikut ini adalah catatan lapangan tentang pembelajaran dengan menggunakan pendekatan mastery learning pada siklus II pertemuan I.

a. Jumlah siswa yang mengemukakan pendapat masih rendah.

b. Siswa jarang mengulangi pelajaran dirumah yang telah diajarkan guru.

c. Ada beberapa siswa yang hanya mendengarkan dan mencatat materi tentang pecahan.

\section{Hasil Observasi Guru Siklus II Pertemuan I}

Pada pertemuan pertama siklus II, guru dalam penguasaan terhadap materi pelajaran yaitu penguasaan bahan materi dengan sangat baik mendapat 4 point, kemudian guru dalam materi pelajaran sesuai dengan standar kompetensi (SK) dan tujuan pembelajaran mendapat 3 point, kemudian guru dalam menyajian materi jelas mendapat 4 point, dan kemudian guru dalam penyajian materi secara sistematis mendapat 3 point.

Pada pelaksanaan identifikasi atau pemilihan strategi instruksional, guru menggunakan pendekatan sesuai dengan yang direncanakan mendapat 4 point, guru dalam melakukan pembelajaran dilaksanakan dengan sistematis mendapat 3 point, guru dalam belajar menggunakan metode yang bervariasi dengan sangat baik mendapat 4 point dan guru dalam kegiatan pembelajaran dapat meningkatkan aktivitas belajar siswa mendapat 3 point.

Dalam kegiatan pemberian instruksi, guru menyimpulkan materi pelajaran dengan baik mendapat 4 point, dalam memberi pengayaan mendapat 2 point, dan dalam memberi tugas guru mendapat 4 point, dan guru dalam menginformasikan materi selanjutnya mendapat 4 point. Deskripsi hasil observasi guru pada pertemuan I dapat dilihat pada tabel lampiran 10. Dari hasil observasi guru dengan menggunakan pendekatan mastery learning pada siklus II pertemuan I diperoleh nilai 87,5 .

\section{Hasil Observasi Aktivitas Siswa Siklus II Pertemuan II}

Pelaksanaan tindakan pada pertemuan kedua ini dihadiri 40 
siswa. Disini guru menjelaskan materi kemudian membagi siswa lagi menjadi beberapa kelompok secara merata untuk mempermudah siswa dalam memahami materi pelajaran. Dari 40 siswa dalam kelas terdapat 40 siswa yang melakukan aktivitas mendengarkan, 40 siswa tersebut mendengarkan penjelasan guru dengan baik, siswa ini juga mendengarkan hasil diskusi kelompok orang lain, 40 siswa mendengarkan dengan baik pendapat teman satu kelompok dan dari hasil observasi terlihat 40 siswa mendengarkan hasil diskusi atau berdiskusi yang persentasenya $100 \%$.

Dapat dilihat bahwa aktivitas belajar siswa telah mengalami peningkatan dari hasil observasi pada siklus II pertemuan 2 telah mengalami peningkatan, persentase ini sudah sesuai dengan yang ditargetkan yakni dengan rata-rata $88,91 \%$ sudah dalam kategori tinggi. Dilihat dari nilai rata-rata secara klasikal dan individu telah tercapai dan sesuai dengan harapan, maka peneliti menghentikan tindakan sampai pada siklus II pertemuan II.

\section{Hasil Observasi Guru Siklus II Pertemuan II}

Pada pertemuan kedua siklus II, guru dalam penguasaan terhadap materi pelajaran yaitu penguasaan bahan materi dengan sangat baik mendapat 4 point, kemudian guru dalam materi pelajaran sesuai dengan standar kompetensi (SK) dan tujuan pembelajaran mendapat 4 point, kemudian guru dalam menyajian materi jelas mendapat 4 point, dan kemudian guru dalam penyajian materi secara sistematis mendapat 4 point.

Dalam kegiatan evaluasi penilaian, guru membuat tes-tes formatif, baik secara terbimbing maupun mandiri mendapat 4 point, guru melihat siswa mendapatkan nilai yang objektif, baik individu maupun kelompok mendapat 4 point, siswa cepat dalam menyelesaikan tugas-tugas mendapat 4 point, guru bisa membuat siswa serius dalam mengerjakan tugas-tugas mendapat 4 point.

Dalam kegiatan pemberian instruksi, guru menyimpulkan materi pelajaran dengan sangat baik mendapat 4 point, dalam memberi pengayaan mendapat 4 point, dan dalam memberi tugas guru mendapat 4 point, dan guru dalam menginformasikan materi selanjutnya mendapat 4 point. Deskripsi hasil observasi guru pada pertemuan II dapat dilihat pada tabel lampiran 11. Dari hasil observasi guru dengan menggunakan pendekatan mastery learning pada siklus II pertemuan II diperoleh nilai 100.

\section{Refleksi II}

Upaya-upaya yang teah dilakukan pada mata pelajaran matematika mengenai penjumlahan dan pengurangan dengan menggunakan pendekatan mastery learning pada siklus II telah mengalami peningkatan dan termasuk dalam kategori tinggi. Dapat dilihat aktivitas belajar siswa secara klasikal dengan rata-rata 
persentase yang sudah meningkat hal ini membuktikan bahwa peneliti telah mampu meningkatkan aktivitas belajar siswa dalam Penjumlahan dan pengurangan pecahan dengan menggunakan pendekatan mastery learning. Dengan melihat hasil observasi aktivitas belajar siswa pada siklus II ini, diketahui bahwa siswa telah mengalami keaktifan secara klasikal dan individu sehingga tidak perlu melakukan tindakan pembelajaran lagi sebab tingkat aktivitasnya sudah tergolong tinggi.

\section{Pembahasan Hasil Penelitian}

Melalui pendekatan mastery learning telah terbukti dapat meningkatkan aktivitas belajar siswa dalam Penjumlahan dan pengurangan pecahan dan terlaksana sesuai dengan target atau yang diharapkan. Dapat dilihat hasil aktivitas belajar siswa secara klasikal telah mengalami peningkatan, dari siklus I pertemuan 1 dengan nilai rata-rata $37,65 \%$ dan siklus I pertemuan 2 dengan nilai rata-rata 50,97\%. Begitu juga dengan frekuensi siswa yang aktif pada siklus I pertemuan 1 ratarata persentase hanya $9,06 \%$ dan setelah dilakukan pembelajaran di siklus I pertemuan 2 maka dapat ratarata persentase frekuensi siswa yang aktif 27,19\%. Berdasarkan kesimpulan sementara bahwa aktivitas belajar siswa belum meningkat sehingga perlu perbaikan pembelajaran yang lebih baik lagi pada siklus II.

Ternyata setelah melakukan perbaikan pembelajaran dengan menggunakan pendekatan yang sama yakni pendekatan mastery learning siswa menjadi lebih bersemangat karena sudah mengeri cara kerja pada pembelajaran mastery learning sehingga membuat siswa aktif dalam belajar. Pada tindakan siklus II, merupakan perbaikan pembelajaran yang dilaksanakan pada siklus I dan nilai rata-rata kelas pada siklus II meningkat dari siklus sebelumnya. Hasil observasi aktivitas belajar pada siklus II pertemuan I dengan nilai rata-rata $68,91 \%$ dan mengalami peningkatan pada siklus II pertemuan 2 dengan nilai rata-rata $88,91 \%$ dan untuk hasil frekuensi siswa yang aktif pada siklus II pertemuan I dengan rata-rata $59,37 \%$ kemudian peneliti melakukan pertemuan 2 dan hasilnya meningkat rata-rata frekuensi siswa yang aktif menjadi 97,81\% termasuk kategori tinggi. Berdasarkan hasil observasi pada siklus I (pertemuan 1 dan 2) dan siklus II (pertemuan 1 dan 2) dapat dilihat peningkatan jumlah siswa yang aktif pada setiap aspek/indikator aktivitas.

\section{Pembahasan hasil observasi} Aktivitas guru

Walaupun pada siklus I guru masih kurang dalam mengajar namun pada saat tahap refleksi pada siklus I guru juga ikut merefleksi diri untuk memperbaiki kelemahan dan memperbaiki pengajaran sehingga aktivitas siswa dalam Penjumlahan dan pengurangan pecahan menjadi meningkat dan sudah sesuai dengan harapan. Setelah melakukan tahap refleksi di siklus I maka di siklus II kinerja guru sudah meningkat dan 
terlihat dari persentase yang didapat oleh guru. Persentase rata-rata yang didapat oleh guru pada saat mengajar termasuk dalam kategori sedang (baik).

\section{SIMPULAN}

Dari hasil pembahasan penelitian dapat ditarik kesimpulan sebagai berikut:

1. Dengan dilakukannya pendekatan mastery learning membuat siswa Kelas II menjadi berani kedepan kelas untuk mengerjakan soal-soal pada mata pelajaran matematika khususnya dalam Penjumlahan dan pengurangan pecahan. Dan peningkatan aktivitas ini dapat dilihat dari indikator aktivitas siswa yang menjadi acuan.

2. Penggunaan pendekatan mastery learning dalam proses belajar mengajar dapat meningkatkan aktivitas dan rangsangan untuk belajar pada siswa sehingga membawa pengaruh yang positif terhadap kegiatan-kegiatan yang dilakukan siswa.

3. Dapat diketahui tingkat persentase aktivitas belajar siswa pada siklus I pertemuan I dengan rata-rata $37,65 \%$. Pada siklus I pertemuan II persentase aktivitas belajar siswa dengan rata-rata $51,88 \%$. Sedangkan pada siklus II pertemuan I secara keseluruhan $68,91 \%$ dan pada siklus II pertemuan II secara keseluruhan mencapai 88,91\%. Maka dapat diketahui bahwa aktivitas belajar siswa mengalami peningkatan dibandingkan kodisi pada siklus I.
4. Tingkat persentase aktivitas guru dengan menggunakan pendekatan mastery learning pada siklus I pertemuan I dengan rata-rata $58,02 \%$. Pada siklus I pertemuan II persentase aktivitas guru dengan rata-rata $70,37 \%$. Sedangkan pada siklus II pertemuan I secara keseluruhan $85,19 \%$ dan pada siklus II pertemuan II secara keseluruhan mencapai 100\%. Maka dapat diketahui bahwa aktivitas guru dalam proses belajar mengajar meningkat pada setiap pertemuan.

5. Secara garis besar dapat disimpulkan pendekatan mastery learning dapat meningkatkan aktivitas belajar siswa Kelas II SD Negeri No. 065853 Kec Medan Denai.

\section{DAFTAR RUJUKAN}

Ahmadi, Lif Khoiru. 2011. Strategi Pembelajaran Berorientasi KTSP. Jakarta: PT. Prestasi Pustakaraya.

Aqib, Zainal. 2006. Penelitian tindakan kelas. Bandung: Yrama Widya.

Dewi, $\quad$ Rosmala. 2010. Professionalisasi Guru Melalui Penelitian Tindakan Kelas. Medan: UNIMED.

Hamalik, Oemar. 2008. Kurikulum dan Pembelajaran. Jakarta: Bumi Aksara. 
Megawati: Meningkatkan Kreativitas....

Kunandar. 2009. Guru Profesional Implementasi Kurikulum Tingkat Satuan Pendidikan (KTSP) dan Sukses dalam Sertifikasi Guru. Jakarta: PT. Raja Grafindo Persada.

Mulyono, Abdurrahman. 2003. Pendidikan Bagi Anak Berkesulitan Belajar. Jakarta: Rineka Cipta.

Natawidjaja, Rochman. 2001. Psikologi Pendidikan. Jakarta: C.V Mutiara.

Sardiman. 2009. Interaksi dan Motivasi Belajar Mengajar.
Jakarta: PT. Raja Grafindo Persada.

Slameto. 2010. Belajar dan faktorfaktor yang mempengaruhinya. Jakarta: Rineka Cipta.

Syaiful. 2009. Konsep dan Makna Pembelajaran. Bandung: Alfabeta.

Yamin, Martinis. 2008. Paradigma Pendidikan Konstruktivistik. Jakarta: Perpustakaan Nasional RI. 